\section{Application of Brushing for Growth Control of Tomato Transplants in a Commercial Setting}

\author{
Joyce G. Latimer ${ }^{1}$ \\ and Paul A. Thomas ${ }^{2}$
}

Additional index words. mechanical conditioning, growth regulation, Lycopersicon esculentum

Summary. Brushing 2-week-old 'Sunny' tomato ( Lycopersicon esculentum Mill.) seedlings, grown in a commercial production greenhouse, for a period of 5 weeks reduced transplant growth and improved plant appearance. Brushing reduced stem length $37 \%$ and leaf area $31 \%$ relative to nontreated control plants. Plants were darker green in color, stockier, easier to handle, and tougher (exhibited less breakage) than nontreated plants.

$\mathrm{W}$ ith the recent loss of Alar (daminozide) for use on vegetable transplants, methods of height control of greenhouse-grown transplants have been limited to water and/or nutrient restriction. Mechanical conditioning shows promise as a nonchemical method of controlling the height and quality of vegetable transplants (Latimer, 1991). Brushing the shoots ofseedlings reduces stem growth and leaf expansion, resulting in shorter, sturdier transplants. Mechanical conditioning in the form of shaking potted tomato plants (Heuchert et al., 1983) or rubbing the stem of bean (Jaffe et al., 1984) increases stem strength. Brushing cucumber transplants reduces plant size and the number of plants broken during field planting (Latimer et al., 1991).

${ }^{7}$ Deparment of Horticulture, Georgia Experiment Station, University of Georgia, Griffin, GA 302231797.

${ }^{2}$ Department of Extension Horticulture, University of Georgia, Athens, GA 30602.
The following research was undertaken in response to a request from a Georgia grower for a nonchemical method of improving the quality of his tomato transplants. This innovative grower was willing to test the brushing technology in his commercial greenhouse.

Seeds of 'Sunny' tomato were sown on 1 Feb. 1991 in Todd 100A flats (cells $2.8 \mathrm{~cm}$ square $\times 7.6 \mathrm{~cm}$ deep, $24 \mathrm{~cm}^{3}$ in volume; Speedling Corp., Sun City, Fla.) filled with a peatlite growing medium (Speedling Fortified Tobacco Mix). The plants were grown in a polyethylene greenhouse with sidewall ventilation. All cultural practices were as used normally by the grower. Brushing was initiated 2 weeks after seeding, when only the cotyledons were expanded. The grower developed a system for brushing the seedlings by suspending a PVC pipe between two wooden blocks resting on the tracks supporting the flats (Fig. 1). Although leaves adhered to the PVC pipe, there was no evidence of physical damage to the leaves of the treated transplants. Use of a wooden or aluminum pole would reduce leaf adherence and still be amenable to the system used. This system, under this type of bench arrangement, required an open aisle on either side of a double row of flats. Additional holes cut in the block of wood allowed the pipe to be

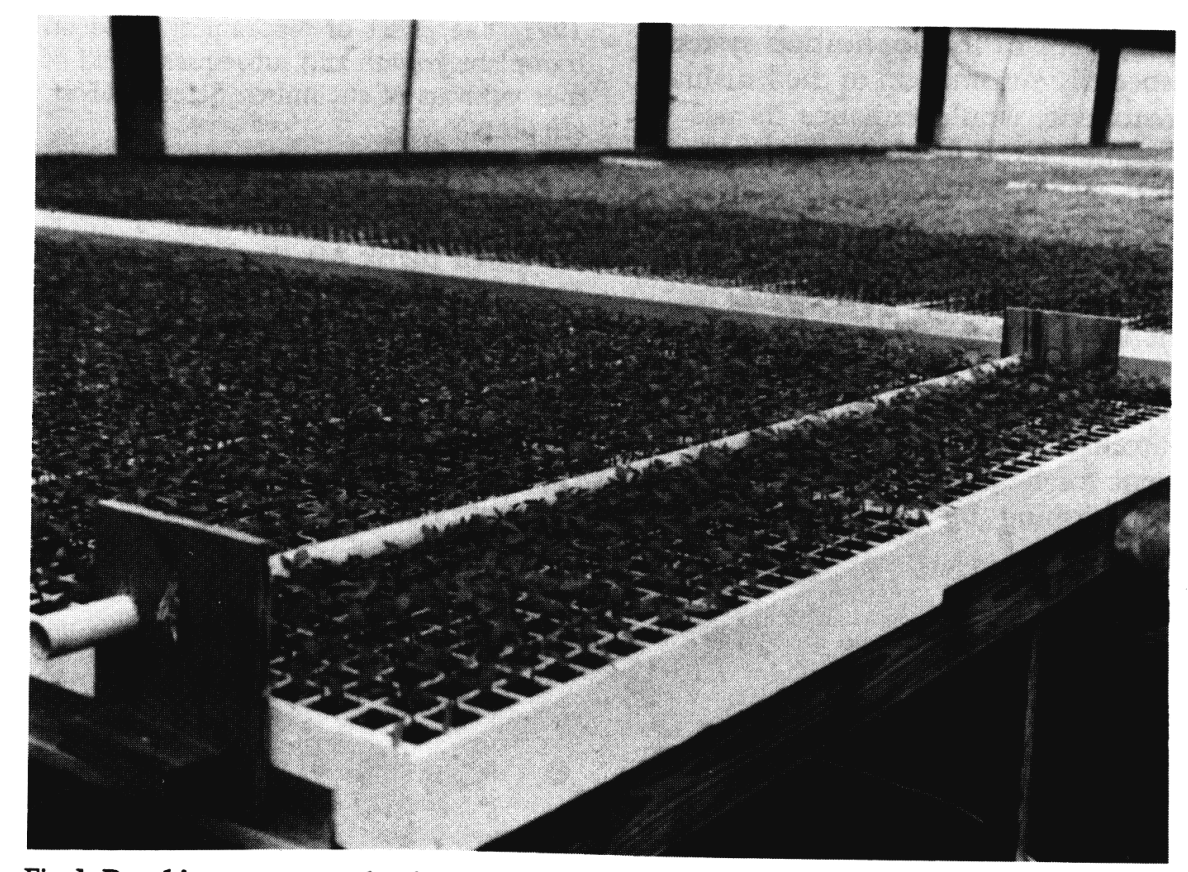

Fig. 1.Brusbing apparatus developed by Mr. and Mrs. Wilber Lanier for rapid treatment of tomato tramplants.

raised as the plants grew, so that only the top one-third of the plant was brushed. The system required two people for 10 to $15 \mathrm{~min}$ to treat each double row containing 28 flats. The seedlings were brushed daily, initially using 25 cycles (one pass back and forth over the flat constituted one cycle), and increasing the treatment to $\approx 35$ cycles for the last 3 to 4 weeks of production.

After 5 weeks of treatment, 30 representative plants were collected from each treatment (control or brushed) for measurement of the following growth characteristics: stem length, leaf area (LI-COR 3000 leaf area; meter, LI-COR, Lincoln, Neb.), and stem, leaf, and petiole dry weights (after drying for $72 \mathrm{~h}$ in a $70 \mathrm{C}$ forcedair oven).

Brushing reduced the overall growth of treated tomato transplants (Table 1), stem length $37 \%$, and leaf area to a greater extent than leaf dry weight, indicating that the leaves were smaller but denser than those of the nontreated plants. Calculation of the specific leaf weight or leaf dry weight per area confirms an $18 \%$ increase in leaf density. Petiole, stem, and shoot dry weights also were reduced by the treatment. Plant appearance was improved: the leaves were darker green and the stems were tougher and more elastic during handling than those of 


\section{PRODUCTION AND MARKETING REPORT}

Table 1. Bffect of brusbing for 5 weeks on the growtb of 7-week-old 'Sunny' tomato transplants $(n=30)$.

\begin{tabular}{lccc}
\hline Measurement & Nontreated & Brushed & $\begin{array}{c}\text { Difference from } \\
\text { nontreated } \\
\text { (\% change) }\end{array}$ \\
\hline Stem length $(\mathrm{cm})$ & 13.6 & $8.5^{* * *}$ & -37 \\
Leaf area $\left(\mathrm{cm}^{2}\right)$ & 42 & $29^{* * *}$ & -31 \\
Leaf dry wt $(\mathrm{mg})$ & 142 & $116^{* *}$ & -18 \\
Petiole dry wt $(\mathrm{mg})$ & 23 & $16^{* * *}$ & -30 \\
Stem dry wt $(\mathrm{mg})$ & 71 & $50^{* * *}$ & -29 \\
Shoot dry wt $(\mathrm{mg})$ & 235 & $182^{* * *}$ & -23 \\
Specific leaf wt $\left(\mathrm{mg} \cdot \mathrm{cm}^{-2}\right)$ & 3.4 & $4.0^{* * *}$ & 18 \\
\hline
\end{tabular}

"." Level of significance, paired test at $\mathrm{P}<0.01$ or 0.001 , respectively.

the controls. The treated plants were judged to be of higher quality than the nontreated plants.

As with any other manual technique, spread of disease organisms is a potential problem with brushing. In this study, which used overhead irrigation, there was no evidence of disease in either the treated or control plants. The role of brushing in pathogen dissemination needs study; however, at present, the only recommendations available are to cull diseased plants to reduce the potential spread of pathogens and to brush only when the foliage is dry.

The results of this study confirm that brushing has the flexibility required for a commercial production system. The grower was able to apply the treatment as it fit his daily schedule and was pleased with his overall growth control and plant quality. Further development of the application system, especially automation of the brushing treatment, would enhance its use in commercial transplant production. Beyl and Mitchell (1977) suggested the use of intermittent blasts of humidified air or "mechanical fingers" drawn across the crop canopy. Attachment of an apparatus to the boom watering system or to tracks on or above the benches would allow easy automation of a brushing type of treatment for height control. Mechanical conditioning by shaking groups of plants or entire benches also may be effective in transplant height control, and this should be easy to automate.

\section{Literature Cited}

Beyl, C.A. and C.A. Mitchell 1977 Automated mechanical stress application for height control of greenhouse chrysanthemum. HortScience 12:575-577.

Heuchert, J.C., J.S. Marks, and CA. Mitchell. 1983. Strengthening of tomato shoots by gyratory shaking. J. Amer. Soc. Hort. Sci. 108:801-805.

Jaffe, M.J., F. W. Telewski, and P. W. Cooke. 1984. Thigmomorphogenesis: On the mechanical properties of mechanically perturbed bean plants. Physiol. Plant. 62:73-78.

Latimer, J.G. 1991. Brushing can control transplant height. Amer. Veg. Grower 39(4):98,102-103.

Latimer, J.G., T. Johjima, and K. Harada. 1991. The effect of mechanical stress on transplant growth and subsequent yield of four cultivars of cucumber. Scientia Hort. (In press.)

\section{Acknowledgements}

We thank Mr. and Mrs. Wilber Lanier, Nevils, Ga., for their willingness to cooperate in this research and commend them on development of the system presented herein. We also thank Mr. Raymond Joyce, Bulloch County Agricultural Extension Service, for his assistance in this research. 